\title{
Geochemistry of Croatian superhigh-organic-sulphur Raša coal, imported low-S coal and bottom ash: their Se and trace metal fingerprints in seawater, clover, foliage and mushroom specimens
}

\section{Gordana Medunić*}

Faculty of Science,

Department of Geology, University of Zagreb,

Zagreb, Croatia

Email: gmedunic@geol.pmf.hr

*Corresponding author

\section{Željka Kuharić and Adela Krivohlavek}

Andrija Štampar Teaching Institute of Public Health, Zagreb, Croatia

Email: Zeljka.Kuharic@stampar.hr

Email: adela.krivohlavek@stampar.hr

\section{Željka Fiket}

Division for Marine and Environmental Research, Ruđer Bošković Institute,

Zagreb, Croatia

Email: zeljka.fiket@irb.hr

\section{Ankica Rađenović}

Faculty of Metallurgy,

University of Zagreb,

Sisak, Croatia

Email: radenova@simet.hr

\section{Kristina Gödel and Štefica Kampić}

Faculty of Science,

Department of Geology,

University of Zagreb,

Zagreb, Croatia

Email: goedel0@gmail.com

Email: skampic@geol.pmf.hr 


\title{
Goran Kniewald
}

Division for Marine and Environmental Research, Ruđer Bošković Institute, Zagreb, Croatia Email: Goran.Kniewald@irb.hr

\begin{abstract}
The Labin City area has represented the major Croatian coal mining, metal industry and coal-fired electricity centre for more than two centuries. The domestic superhigh-organic-sulphur (SHOS) Raša coal is a unique variety compared to other coal types worldwide, based on its highest organic sulphur values, up to $11 \%$. It was utilised in the Plomin coal-fired power plant during the period 1970-2000, and was replaced by an imported low-S coal afterwards. This paper presents the levels of $\mathrm{S}, \mathrm{Se}, \mathrm{V}, \mathrm{U}, \mathrm{Hg}, \mathrm{Sr}, \mathrm{Cd}, \mathrm{Cr}, \mathrm{Pb}, \mathrm{Cu}$ and $\mathrm{Zn}$ in the two coal types, their bottom ash, seawater and plant (clover, mushroom and foliage) specimens collected from the Labin City area, while the sulphate was measured in surface stream water. Their levels were compared with relevant legislative as well as the published data from different world localities. Data analysis was interpreted in the context of past and recent coal combustion activities. [Received: March 15, 2017; Accepted: April 28, 2017]
\end{abstract}

Keywords: SHOS Raša coal; low-S coal; bottom ash; sulphur; selenium; uranium; vanadium; seawater; clover; foliage; mushroom; trace elements.

Reference to this paper should be made as follows: Medunić, G., Kuharić, Ž., Krivohlavek, A., Fiket, Ž., Rađenović, A., Gödel, K., Kampić, Š. and Kniewald, G. (2018) 'Geochemistry of Croatian superhigh-organic-sulphur Raša coal, imported low-S coal and bottom ash: their Se and trace metal fingerprints in seawater, clover, foliage and mushroom specimens', Int. J. Oil, Gas and Coal Technology, Vol. 18, Nos. 1/2, pp.3-24.

Biographical notes: Gordana Medunić is an Associate Professor of Geochemistry and Statistics of Earth Science Data at the Department of Geology (Faculty of Science, University of Zagreb, Croatia). Her current study is focused on the locality highly polluted with organic and inorganic compounds (legacy of the super high-organic-sulphur Raša coal mining/combustion and associated metal industry) situated in the coastal karst environment. She coauthored more than 40 scientific papers, some 20 of them in CC journals. She also coauthored one textbook in geostatistics. She gave several scientific talks at the US and Japanese universities.

Željka Kuharić is an analyst in Andrija Stampar Teaching Institute of Public Health (Department of Environmental Protection and Health Ecology). Currently, she is on $\mathrm{PhD}$ Program in Faculty of Food Technology and Biotechnology. She works on development of new methods in field of liquid chromatography and atomic mass spectrometry. She has worked in Helmholtz Institute in Munich within Croatian-German Research project 'Diabetes mellitus Type 2 in the Croatian Population after Chronic Exposure to Arsenic'.

Adela Krivohlavek is a Senior Professional Associate, Head of the Department of Environmental Protection and Health Ecology in Dr Andrija Štampar Teaching Institute of Public Health, Zagreb, Croatia. Her current study is focused on the examination of health correctness and quality of food samples, 
objects of common use and other environmental samples, such as: water, air, soil, waste and waste waters, and implementation of testing procedures in order to assess and improve monitoring of health of citizens and preserving the environment. She is co-author of ten scientific papers; 60 abstracts published in books of abstracts from scientific conferences; and 32 citations (source: Scopus database).

Željka Fiket is a Research Associate in the Laboratory for Inorganic Environmental Geochemistry and Chemodynamics of Nanoparticles, Division for Marine and Environmental Research, Rudjer Boskovic Institute in Zagreb, Croatia. She graduated with a BSc degree in Geology in 2001, and a PhD degree in Geosciences, Oceanology in 2014 from the University of Zagreb. She held a post-doctoral position during 2015-2016 at the Faculty of Natural Sciences, Ljubljana, Slovenia. She has received the L'Oreal/UNESCO award for Women in Science in 2013. She (co)authored 21 scientific papers quoted by Web of Science.

Ankica Rađenović is a Full Professor at the University of Zagreb Faculty of Metallurgy. Her research activities have continuously been dedicated to the scientific disciplines: (1) Carbon materials, specially properties and application of coal, metallurgical coke, petroleum coke, carbon black; and (2) Use of $\mathrm{a}$ - the carbonaceous materials and $\mathrm{b}$ - waste and by-products of iron and steelmaking industry, as an adsorbent for removal of toxic substances from the water/wastewater. She authored/coauthored more than 50 scientific papers, some 15 of them in CC journals. She also authored/coauthored textbooks in carbon materials and refractories materials.

Kristina Gödel finished undergraduate study of Geology with the theme: 'Sulfur in the soil and sulphates in the water from Labin region'. She is studying graduate study of Environmental Geology at Department of Geology within Faculty of Science, University of Zagreb. Her fields of interest are environmental sciences and ore deposits with a focus on geochemistry.

Štefica Kampić is employed as a Senior Advisor to Mineralogy and Petrology Department of Geology at the Faculty of Science in Zagreb. She graduated from the Faculty of Food Technology, University of Zagreb, Department of Biochemical Engineering. She deals with professional and teaching activities in the chemical laboratory on work related to the quantitative analysis of minerals and rocks and analysis related to the soil.

Goran Kniewald received his $\mathrm{PhD}$ degree in 1991 from the University of Zagreb, Croatia, after studying and receiving also his Bachelor and Master's degree in geology and geochemistry from the same University. Currently, he is a Senior Scientist and Head of the Laboratory for Inorganic Environmental Geochemistry in the Division of Marine and Environmental Research. He is also a Full Professor of Environmental Sciences at the Universities of Zagreb and Rijeka. From 1996 to 2008, he was a Visiting Professor at the Toulon-Sud-Var University in France. He is an expert panel member of the Environmental Crime Committee of the International Police Organization INTERPOL and a member of the NATO Independent Scientific Evaluation Group - ISEG. 


\section{Introduction}

Coal accounts for the most important energy source in many parts of the world. It is the most complex geological material, composed of organic matter, water, oil, methane gas, and virtually all the elements in the periodic table, together with a wide variety of minerals (Finkelman, 1994; Rađenović, 2006; Vejahati et al., 2010). Low-quality coals are characterised by high sulphur, high ash and high levels of potentially toxic trace elements. Among them, sulphur is a particularly interesting component, which, along with nitrogen and phosphorous, is an essential element for all living matter. Its characterisation, occurrence, ecotoxicology and environmental fate have been studied extensively using various scientific approaches (Oden, 1976; Zerklea et al., 2010; Senko et al., 2011; Kuklińska et al., 2013; Saikia et al., 2015; Sołek-Podwika et al., 2016). It is ubiquitously present on Earth, existing in soils, seawater and plants in organic, sulphate, and sulphide forms, whereas in gaseous and solid states in the atmosphere (Badr and Probert, 1994). Since $\mathrm{SO}_{2}$ has been emitted whenever fuels containing sulphur, like coal, coke and oil, are burnt, its main anthropogenic emission sources are coal-fired power plants, central-heating stations, and industrial furnaces in the iron and steel industry (Speight, 2013). Herewith, a considerable amount of research of sulphur emission processes, pathways, budgets and environmental issues has been published so far (Speight, 2005; Baruah and Khare, 2010; Bläsing et al., 2015; Saikia and Ninomiya, 2011; Saikia et al., 2015; Dutta et al., 2017). Although the sulphur content in coal varies considerably, its total levels most commonly range from $0.50 \%$ to $5.00 \%$ (Rađenović, 2004; Chou, 2012). Fulekar and Dave (1986) reported that the total S content in major Indian coals (except those of Assam, Jammu and Kashmir which contain $\mathrm{S}$ up to $14.0 \%$, and are not used in power plants) are between $0.20 \%$ and $1.40 \%$. Superhigh-organic-sulphur (SHOS) coal is a special class of coal, characterised by remarkably elevated values of organic $S$, usually in the range of $4.00-11.0 \%$. Due to its limited distribution in the world, there are only several papers concerned with such unusual coal. These are following: the Cenozoic coals of the Gippsland Basin, Victoria, Australia (Smith and Batts, 1974), a Permian coal seam in the Cranky Corner Basin, eastern Australia (Marshall and Draycott, 1954; Ward et al., 2007), and some Lopingian coals preserved within marine carbonate successions in southern China Guiding (Guizhou Province), Yanshan (Yunnan Province), Heshan and Fusui (Guangxi Province) (Dai et al., 2008, 2013a, 2013b, 2015). Chou (1997) compared organic S in Chinese SHOS coals Guidin (up to 9.18\%) and Yanshan (up to 10.3\%), with Croatian SHOS Raša coal (10.5\%). According to Sinninghe Damsté et al. (1999), SHOS Raša coal is characterised by unusually high amount of sulphur $(11.8 \%)$, which is largely present in the form of anomalously high level of organic S (11.4\%). The authors concluded that Raša coal is not a typical coal, as the organic matter had not been derived from the higher terrestrial plants. White et al. (1990) carried out the petrographic, proximate, and ultimate analyses of Raša coal, and they also reported information on the vitrinite reflectance, carbon aromaticity, sulphur and carbon isotopic abundances, ash analysis and forms of sulphur. They stated that "for the scientist interested in characterizing organic sulphur components in coal, Raša coal is a good starting point". The paper comprehensively refers on previously published publications (since early 1950s) pertinent to Raša coal geology and organic geochemistry. Briefly, the Raša coal-bearing strata represent the Upper Paleocene lacustrine and brackish facies. 
Recently, Medunić et al. (2016a) reviewed historical, geological, geochemical and environmental aspects of the Raša coal mines located on the eastern part (Figure 1) of the Istrian Peninsula (Labin City area, North Adriatic, Croatia). They had been by far the most important and economically the most valuable deposits of the lignite (a high volatile B bituminous rank) coal reserves in Croatia since the 18th century till 1999, when their excavation and use in the local Plomin coal-fired power plant (PPP) ceased. The characteristics of Raša coal were reported as follows: total moisture $5.80-19.1 \mathrm{wt} \%$, ash content 10.3-23.9 wt \%, combustibles $66.0-84.0 \mathrm{wt} \%$, low heat value $18,400-26,300 \mathrm{~kJ} / \mathrm{kg}$, carbon $58.3-67.5 \mathrm{wt} \%$, hydrogen $4.10-5.00 \mathrm{wt} \%$, S (org.) 7.90-10.6 wt\%, oxygen 5.90-12.9 $\mathrm{wt} \%$ and nitrogen $1.00-1.80 \mathrm{wt} \%$ (Limić and Valković, 1986). Raša coal had powered not only local households, but also many various industries in Croatia and in Italy. Due to the lack of a proper desulphurisation technology, during each hour of operation the PPP had emitted nearly 8.50 tons $\left(18,080 \mathrm{mg} / \mathrm{m}^{3}\right.$ or $6,900 \mathrm{mg} / \mathrm{kg}$ ) of $\mathrm{SO}_{2}$ during the period 1970-2000 (Mohorović, 2003). This has resulted in the soil pollution with S, PAHs, Se and Cd (Medunić et al., 2016b), and prominent soil REE patterns (Fiket et al., 2016). As the Raša coal was characterised by an enhanced radioactivity, soil around an ash waste site (near the PPP) was also found to have elevated radioactivity (Ernečić et al., 2014). Marović et al. (2004) reported that the activity of U-238 was $500-1,200 \mathrm{~Bq} / \mathrm{kg}$ in 1970 s and $250-300 \mathrm{~Bq} / \mathrm{kg}$ in $1980 \mathrm{~s}$, which was 10-15 times higher than the average of other coal types in the world. Bauman and Horvat (1981) reported natural U ranges in Raša coal from $14.0 \mathrm{mg} / \mathrm{kg}$ to $100 \mathrm{mg} / \mathrm{kg}$ (occasionally up to $1,500 \mathrm{mg} / \mathrm{kg}$ ), whilst natural radioactivity of ash and slag was enhanced by a factor of ten. Also, the authors found higher values of ${ }^{210} \mathrm{~Pb}$ in urine and chromosome aberrations of an exposed group of workers in the PPP. Also, high uranium SHOS coals from China were reported by Dai et al. (2008, 2013a, 2013b, 2015).

Stergaršek et al. (1988) reported that Raša coal was characterised by increased levels of $\mathrm{S}, \mathrm{Ca}, \mathrm{U}$ and $\mathrm{V}$. The authors found out that the ash had also very specific characteristics, particularly high levels of $\mathrm{U}$ and $\mathrm{V}$, thus serving as a potential source of the two metals. Furthermore, the authors reported that Raša coal had $15.0 \%$ of ash, which was alkaline and distributed as 70:30 fly ash: bottom ash (slag). An average composition (\%) of the Raša coal ash was following: $\mathrm{SiO}_{2}$ 1.90, $\mathrm{Al}_{2} \mathrm{O}_{3} 3.27, \mathrm{Fe}_{2} \mathrm{O}_{3}$ 4.59, $\mathrm{CaO}$ 64.2, $\mathrm{MgO}$ 3.79, $\mathrm{Na}_{2} \mathrm{O} 1.42, \mathrm{~K}_{2} \mathrm{O} 0.19$ and $\mathrm{SO}_{3} 20.5$ (Stergaršek et al., 1988). Dai et al. (2013b, 2015) also discussed the enrichment of V-Cr-Mo-Se-Re-U in SHOS coals. Considering the ash, Valković et al. (1984) analysed the Raša coal fly ash by X-ray emission spectroscopy and proton microbeam facilities, and reported the following element data $(\mathrm{mg} / \mathrm{kg})$ : S 1.3E04, Ca 7.8E04, Ti 1,200, V 969, Cr 439, Fe 2.2E04, Ni 65.0, Cu 72.0, Zn 37.0, Ga 10.0, As 21.0, Se 78.0, Pb 19.0, Rb 16.0, U 207, $\mathrm{Sr} 1,800$ and $\mathrm{Y}$ 11.0. Regarding the mineral composition of analysed fly ash, the authors reported following phases: $\mathrm{CaSO}_{4}, \mathrm{CaO}, \mathrm{FeS}_{2}, \mathrm{FeSO}_{4} \times \mathrm{H}_{2} \mathrm{O}, \mathrm{Ca}(\mathrm{OH})_{2}$ and amorphous material. Limić and Valković (1986) analysed two Raša coal regions, $400 \mathrm{~m}$ apart, where coal samples $(\mathrm{n}=265)$ were collected simultaneously with the exploitation. Element ranges (all in $\mathrm{mg} / \mathrm{kg}$ except for $\mathrm{S}, \mathrm{Ca}$ and $\mathrm{Fe}$ in \%) were as follows: $\mathrm{S}$ 6.00-9.00, Ca 2.90-9.00, Fe $0.70-1.30$, Ti $386-665$, V 341-1,500, Cr 106-663, Ni 24.6-48.9, Cu 26.8-50.9, Zn 11.2-26.8, Ga 6.80-20.3, As 3.90-32.9, Se 84.3-153, Pb 2.70-10.0, Rb 8.10-16.7, U 56.0-140 and Sr 192-370. By applying geostatistical methods on the data, the authors established the same genesis for $\mathrm{Ca}, \mathrm{S}, \mathrm{Fe}, \mathrm{Ti}$ and $\mathrm{V}$ in the investigated coal seam. 
To the best of our knowledge, the Labin City area has not been studied as regards the distribution of potentially toxic trace elements and dissolved sulphate in the aquatic and vegetative environmental compartments related primarily to the past Raša coal mining and industrial activities. Therefore, the aim of this study is to report the sulphur, selenium, and trace metal levels in two coal types (SHOS Raša coal and low-S imported coal), and the respective bottom ash specimens. In order to get an insight into their possible trace metal(loid) influence on the local environment, seawater (the Plomin bay, Adriatic Sea) and plant (clover, mushroom and foliage) communities were sampled and analysed. Additionally, the sulphate levels were measured in surface streams (natural stream as well as municipal sewage effluent water) from the old coal mining towns of Raša and Krapan (Figure 1). All data were compared with legislative and other relevant published data from different world localities. Their interpretation was carried out based on the past Raša coal combustion as well as the recent low-S coal combustion activities.

\section{Materials and methods}

\subsection{Study area and sampling description}

The study area (Figure 1) is situated inside the $10 \mathrm{~km}$ radius around the Labin City $\left(45^{\circ} 06^{\prime} \mathrm{N} 14^{\circ} 07^{\prime} \mathrm{E}\right)$. Regarding the geological, hydrological and hydrographical setting, more details can be found elsewhere (Durn et al., 1999; Peh et al., 2010; Halamić et al., 2012; Frančišković-Bilinski et al., 2014). Briefly, the most prominent geological characteristic of the study area is the karst topography and carbonate bedrock. The local and regional terrain is overlain by thin reddish or brownish clay-loam soil, which belongs to the class of Cambic soils. The area is characterised by the Mediterranean climate, with mild humid winters and hot dry summers. According to the wind rose issued by the Croatian Meteorological and Hydrological Service (presented in Medunić et al., 2016b), the dominant NE winds carry airborne gases and dust load from the PPP $\left(45^{\circ} 08^{\prime} 11^{\prime \prime} \mathrm{N}\right.$ $\left.14^{\circ} 09^{\prime} 54^{\prime} \mathrm{E}\right)$ towards the City of Labin, which is situated on a $200-300 \mathrm{~m}$ tall plateau.

Four Raša coal (SHOS) samples (mined and collected in early 1980s) were selected from the Ruđer Bošković Institute archive (Zagreb, Croatia), while two imported low-S coal (C) samples were obtained in late 2015. An old bottom ash waste site (A (SHOS)), which had been accumulated due to the Raša coal combustion until 1950s, is situated at the Štrmac village locality $\left(45^{\circ} 07^{\prime} 19^{\prime \prime} \mathrm{N} 14^{\circ} 07^{\prime} 32^{\prime \prime} \mathrm{E}\right), 2-3 \mathrm{~km}$ north of Labin City (Figures $1 \mathrm{~B}$ and $1 \mathrm{C}$ ). Its various surface parts were randomly sampled with a clean sampling shovel in June 2016. Two samples (one of a grey/light colour and the other one of a dark/black colour) of the low-S coal combustion bottom ash (A) were taken from several-kg material collected from the PPP's vicinity in April 2014. Surface municipal effluent stream water (Figure 1E; non-filtered) and plants (one sample from each plant species, i.e., clover, foliage and mushroom; Figures 1B and 1D) samples were collected in November 2015, while one sample of seawater (non-filtered; SW) was taken from the Plomin Bay $\left(45^{\circ} 08^{\prime} 13^{\prime} \mathrm{N} 14^{\circ} 10^{\prime} 52^{\prime \prime}\right.$ E; Figure 1B) in June 2016.

Coal and ash samples were disaggregated and crushed in an agate mortar. The plant parts were washed first with tap water, then with distilled water and rinsed with deionised water. Afterwards, they were dried in an oven at $60^{\circ} \mathrm{C}$ for a few days, and finally crushed in an agate mortar. The surface stream water (sulphate analysis, $\mathrm{n}=5$ ) and seawater (trace element analysis, $\mathrm{n}=1$ ) samples were collected in clean plastic bottles, where the 
latter one was spiked with suprapure $\mathrm{HNO} 3$, and all the bottles were stored at $2{ }^{\circ} \mathrm{C}$ prior to analyses.

Figure 1 Map of the study area, (A) geographical position (square) (B) sampling sites: $\breve{\text { S }}$ (Strmac) - the A (SHOS) site; SW - seawater (Plomin Bay); F, M, C - foliage, mushroom and clover sampling sites, respectively (C) field situation at the $\breve{S}$ site, (D) the plant sampling site (PPP's stack is some 700-900 m away) (E) surface municipal effluent water (water samples for sulphate analysis) located in the Raša and Krapan towns [Figure 1B; Krapan is located 1-2 km NE of Raša] (see online version for colours)

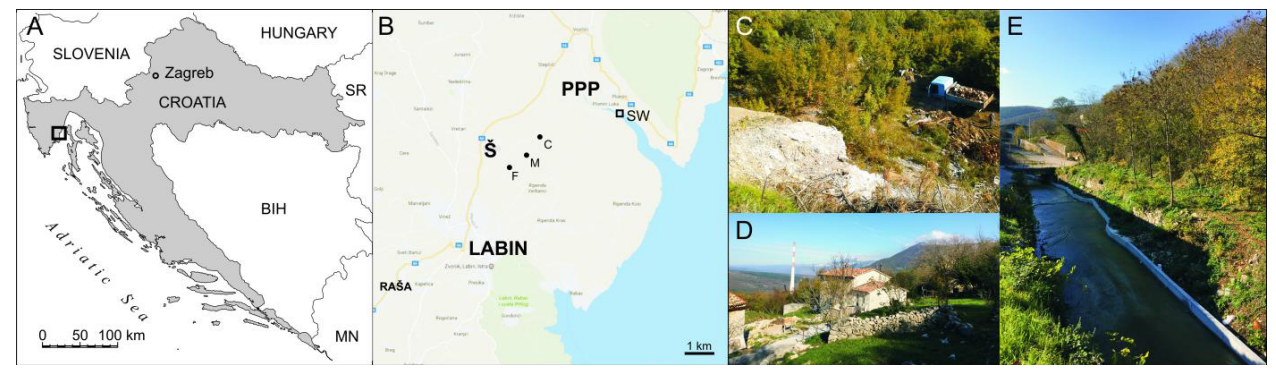

A small village of Štrmac came out of anonymity at the 1880 s when the nearby coalfields were discovered. In the vicinity of a coal mine, lots of buildings (houses, shops, factories, etc.) soon appeared. They had lasted until 1955, when the last tons of coal were excavated. Five years later, the coal-fired power plant's stack together with a mining tower were demolished. Furthermore, the activity of an old local foundry had gradually declined. Today, mostly descendants of miners live there. Also, the A (SHOS) site serves as a landfill for various non-hazardous wastes (Figure 1C).

\subsection{Analytical methods}

Elemental composition of the C, A (SHOS) and plant specimens was determined by atomic absorption spectroscopy, while the SHOS, A and SW specimens were analysed by high resolution inductively couppled plasma - mass spectroscopy. Subsamples (0.1 g) of SHOS and A were subjected to total digestion in the microwave oven (Multiwave 3000, Anton Paar, Graz, Austria). The two-step procedure consisted of digestion with a mixture of 4-mL nitric acid (HNO3) - $1 \mathrm{~mL}$ hydrochloric acid $(\mathrm{HCl})-1 \mathrm{~mL}$ hydrofluoric acid (HF) followed by the addition of $6 \mathrm{~mL}$ of boric acid $\left(\mathrm{H}_{3} \mathrm{BO}_{3}\right)$. After digestion, each solution was transferred into a pre-cleaned plastic volumetric flask and diluted to $100 \mathrm{~mL}$. Prior to analysis, SHOS and A digests and SW samples were further diluted 10 fold and acidified with 2\% (v/v) HNO3 (65\%, supra pur, Fluka, Steinheim, Switzerland), whilst In $(1 \mu \mathrm{g} / \mathrm{L})$ was added as an internal standard. All SHOS, A and SW samples were analysed for total concentration of $\mathrm{Se}, \mathrm{V}, \mathrm{U}, \mathrm{Sr}, \mathrm{Cd}, \mathrm{Cr}, \mathrm{Pb}, \mathrm{Cu}$ and $\mathrm{Zn}$ using an Element 2 HR-ICP-MS instrument (Thermo, Bremen, Germany). Detailed method description is given elsewhere (Fiket et al., 2007; Fiket et al., 2016). Quality control was performed by simultaneous analysis of the blank and certified reference material soil (NCS DC 77302, also known as GBW 07410, China National Analysis Center for Iron and Steel, Beijing, China) and water (SLRS-4, NRC, Canada). Good 
agreement $( \pm 10 \%)$ between analysed and certified concentrations was obtained for all the measured elements.

Mercury was determined by means of the mercury/hydride atomic absorption technique. Monovalent or divalent $\mathrm{Hg}$ and organic mercury are oxidised into divalent mercury with $\mathrm{KBrO} 3$ and $\mathrm{KBr}$. Then, it gets reduced to the elemental form with sodium borohydride in an acidic media. By using stream of argon, the dissolved elemental mercury is conveyed into the cuvette, heated at $100^{\circ} \mathrm{C}$. The measurement conditions were following: $\mathrm{Hg}$ tube, the absorbance wavelength of $253.7 \mathrm{~nm}$, slit $0.7 \mathrm{~nm}$, sample volume $500 \mu \mathrm{L}$, and measurement of peak heights. Flame AAS was used for the determination of other trace elements $(\mathrm{Cd}, \mathrm{V}, \mathrm{Se}, \mathrm{Pb}, \mathrm{Sr}, \mathrm{Cr}, \mathrm{Zn}, \mathrm{Cu}$ and $\mathrm{U})$. The acidified samples were directly introduced in the flame atomic absorption spectrophotometer. When a ray of light passes through a cloud of free atoms in flames, the light absorption of selected elements occurs. The measurement conditions were following: an element tube, element specific absorbance wavelengths, slit 0.7/0.2, flame acetylene-air, and measurement of peak heights. Plant samples were digested in a microwave ETHOS SEL Milestone device. The procedure was as follows: about $0.1 \mathrm{~g}$ of a sample was placed in a Teflon cuvette, and $4 \mathrm{~mL}$ of aqua regia ( $1 \mathrm{~mL} \mathrm{HNO} 3(65 \%)$, and $3 \mathrm{~mL}$ of $\mathrm{HCl}(37 \%)$ was added. The digestion program included $4 \mathrm{~min}$ at $300 \mathrm{~W}, 1 \mathrm{~min}$ at $600 \mathrm{~W}, 1 \mathrm{~min}$ at $0 \mathrm{~W}$, and finally $2 \mathrm{~min}$ at $300 \mathrm{~W}$. Following the digestion, the cuvettes were removed from the microwave device, left to cool to room temperature, and the content was transferred into a volumetric flask of $25 \mathrm{~mL}$, and then diluted with distilled water to the mark.

Total sulphur content (\%) in coal and ash samples was determined using the Eschka's mixture according to the standard test method ASTM E775-87 (1996).

Sulphate in fresh surface water was determined by volumetric method that is based on the amount of sulphate which can be determined by the deposition of sulphate anions in excess of barium chloride. An excess of barium cations is deposited with an excess of potassium chromate, while an excess of chromate anions is measured by iodometric titration with sodium thiosulphate. Reagents included: indicator methylorange, hydrochloric acid $(0.1 \mathrm{M})$, barium chloride solution, potassium chromate, a solution of aluminium chloride $(10 \%)$, a solution of potassium hydroxide $(0.1 \mathrm{M})$, a solution of potassium iodide (10\%), hydrochloric acid (25\%), a standard solution of sodium thiosulphate pentahydrate, and a starch solution as an indicator. The procedure was as follows:

$1100 \mathrm{~mL}$ of a water sample was placed in the Erlenmeyer flask, then $0.1 \mathrm{~mL}$ of methyl orange indicator was added, and the solution was titrated with $0.1 \mathrm{M} \mathrm{HCl}$ until the orange colour of the sample was obtained

2 In this solution, $1 \mathrm{~mL}$ of $0.1 \mathrm{M} \mathrm{HCl}$ in excess was added and $25 \mathrm{~mL}$ of the barium chloride solution. It was necessary to put in a few glass beads for boiling, cover and heat to boiling.

3 Then, the flask was rapidly cooled in a water bath.

4 Following the standing for 30 minutes, $25 \mathrm{~mL}$ of potassium chromate solution, one drop of potassium chloride, and $1.6 \mathrm{~mL}$ of $0.1 \mathrm{M}$ potassium chloride solution were added, and left to stand for about an hour.

5 The solution was filtered without washing the residue, until $100 \mathrm{~mL}$ of the filtrate was ready in the Erlenmeyer flask for the determination of iodine. Then, $10 \mathrm{~mL}$ of 
freshly prepared solution of potassium iodide, and $5 \mathrm{~mL}$ of $\mathrm{HCl}$ were added to the filtrate, and allowed it to stand. The last step was titration with standard solution of sodium thiosulphate using starch as an indicator until a significant change in colour.

\section{Results and discussion}

The previous paper (Medunić et al., 2016b) is an example of the integration of data from several disciplines which should contribute to the canon of knowledge about potential health effects of the SHOS coal combustion. The authors confirmed that soil surrounding the PPP had been polluted primarily by the SHOS Raša coal combustion decades ago. The downwind soil locations were found to be severely polluted with $\mathrm{S}$ (up to $4.00 \%$ ) and PAHs (up to $13,500 \mathrm{ng} / \mathrm{g}$ ), while moderately polluted with Se (up to $6.80 \mathrm{mg} / \mathrm{kg}$ ) and Cd (up to $4.70 \mathrm{mg} / \mathrm{kg}$ ). Also, the cytotoxic effects on fish cells of water extracts of the most polluted soil and ash (the black A sample) were statistically significant. The most important issue is the fact that the investigated locality is situated inside the coastal karst environment (Figure 1), which is well known for its vulnerability. Therefore, it is important to evaluate the environmental quality of other local sites previously or recently exposed to coal and/or ash airborne particles. Commonly, the preliminary analyses involve the elemental composition of aquatic and vegetative samples, and then links with coal and ash geochemical fingerprint elements are established. Therefore, geochemical features of the coal and ash samples will be discussed first, followed by an explanation of the geochemical nature of the aquatic and herbal changes presumably caused by the past as well as recent coal combustion activities.

\subsection{Coal and ash geochemistry}

Figures 2 and 3 show the basic statistical parameters of the variables measured in the coal and ash samples with respect to the Clarke values for the hard coal/coal ashes (Ketris and Yudovich, 2009). Although expected, the most striking feature is the fact that the SHOS and A (SHOS) samples exhibited much higher levels of S compared with the $\mathrm{C}$ and $\mathrm{A}$ samples. Similar high total (6.57-11.2\%) as well as organic (5.01-9.87\%) S values were reported by Liu et al. (2015) for Chinese SHOS coals from Guiding and Yanshan coalfields. Coals rich in sulphur are exploited in NE India (Baruah and Khare, 2010), and Indonesia (Singh et al., 2015), characterised by $\mathrm{S}$ values (\%) up to $5.70(75.0-90.0 \% \mathrm{~S}$ is in the organic form), and 5.40, respectively. The both coals have been geochemically interpreted in the context of the past formation processes in estuarine and lagoonal environments subjected to recurrent marine transgressions. White et al. (1990) pointed out that Raša coal had generated substantial interest over the decades due to its highly increased organic sulphur levels. Based on geological study (Hamrla, 1960), they quoted that the Raša coal-forming plants (few if any higher plants) lived in lacustrine and/or brackish environmental conditions, while their debris had been periodically inundated with seawater. The coal beds are overlain by marine limestones and flysch lithologies. Chou (2012), having reviewed coal sulphur composition, reported that SHOS coals are generally considered to have been formed in clastic-starved basins characterised by algal accumulations and significant influence of seawater. According to Chou (1997), low-pyrite SHOS coals (e.g., Raša coal) were formed in tidal flat environments of 
carbonate platforms profoundly influenced by seawater which supplied sulphur, while iron was scarce. On Figure 1 in Chou (1997), it is shown that the Raša coal is a unique coal worldwide, as it is characterised by the highest organic sulphur values (up to $11.0 \%$ ), and the lowest pyritic and sulphate (below $0.50 \%$ ) sulphur levels. Generally, sulphur is the most abundant heteroatom in coals. While in low-S coal $(<1.00 \% \mathrm{~S})$ sulphur derives primarily from parent plant material, in medium-S $(1$ to $<3.00 \% \mathrm{~S})$, and high-S $(\geq 3.00 \%$ S) coals there are two major sources of sulphur:

1 parent plant material

2 sulphate from seawater that flooded peat swamps (Chou, 2012).

Figure 2 Comparison of the measured data (C, SHOS, A, and A (SHOS), symbols explained in the main text) with world Clarke values
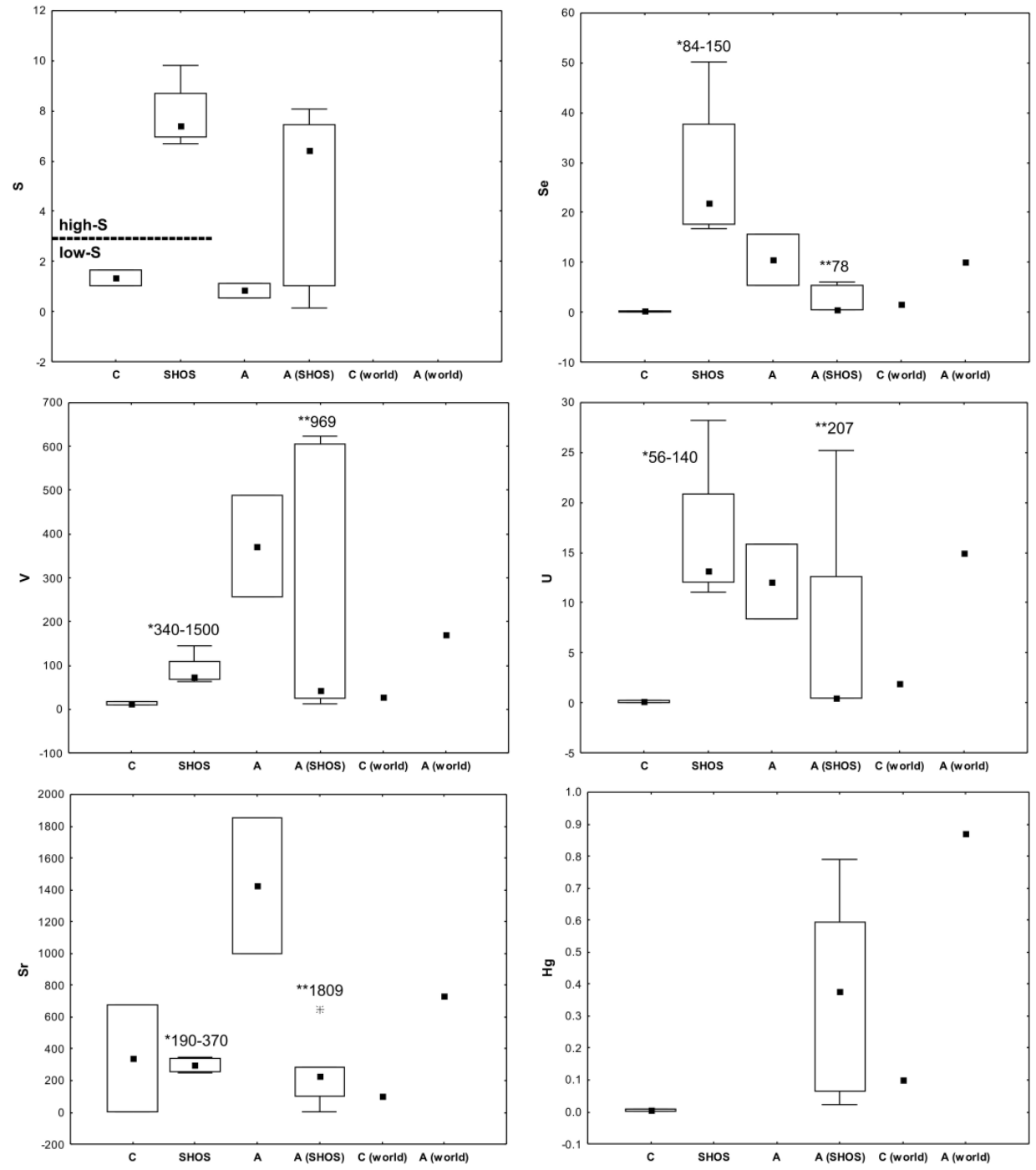

Source: Ketris and Yudovich (2009) 
Figure 3 Comparison of the measured data (C, SHOS, A, and A (SHOS), symbols explained in the main text) with world Clarke values
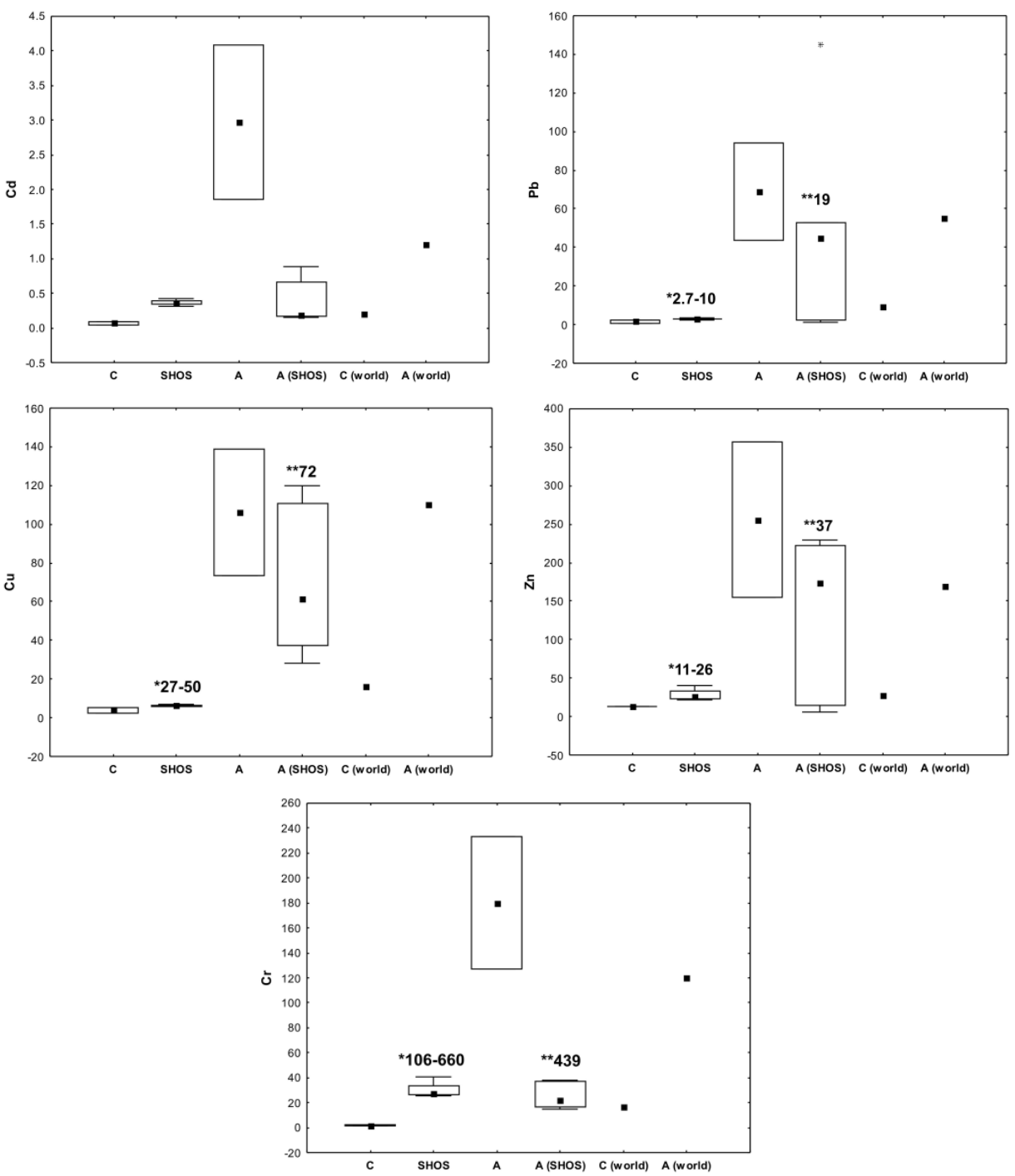

Source: Ketris and Yudovich (2009)

The organic sulphur compounds in coals may be classified into three categories:

1 thiols

2 sulphides and disulphides

3 thiophene and its derivatives.

The sulphur-containing aromatic compounds (benzothiophene, dibenzothiophene and benzonaphthothiophene) were found in bituminous coal and anthracite, but not in lignite (Kasrai et al., 1996). Thus, the abundance of various types of organic sulphur compounds 
in coal may be related to its rank. In contrast to inorganic sulphur (such as pyrite) which can be isolated by physical methods, organic sulphur is the part of the coal structure, and cannot be removed by physical methods (Rađenović, 2004). White et al. (1990) found out families of compounds in the Raša coal containing both $\mathrm{N}$ and $\mathrm{S} ; \mathrm{S}$ and $\mathrm{O}$; and $\mathrm{S}, \mathrm{N}$ and $\mathrm{O}$; they emphasised that it was "rare to observe a homologous series of compounds from coal that contains three different heteroatoms".

Figure 2 shows that the SHOS Se and U values are markedly increased compared to coal Clarke values, especially when previously published values (Limić and Valković, 1986) are taken into account. Similar levels of Se $(26.7-31.4 \mathrm{mg} / \mathrm{kg})$, and U $(167-264 \mathrm{mg} / \mathrm{kg}$ ) in Chinese SHOS coal were reported by Liu et al. (2015). Chou (1990) pointed out that high-S coals are enriched in certain major and trace elements (e.g., B, Fe, $\mathrm{Mo}, \mathrm{Hg}, \mathrm{Tl}$ and $\mathrm{U}$ ) compared with low- and medium-S coal varieties. Likewise sulphur, the author links B, Mo and $\mathrm{U}$ to the seawater which flooded a swamp and terminated peat accumulation. According to Yudovich and Ketris (2006), sulphates commonly occur in the environment due to high mobility of S, while selenates exist only in strongly oxidising and alkaline environments as Se is far less mobile than S. The authors clearly elaborated numerous important facts about selenium in coal, and a few of them are displayed here as follows:

1 Se-bearing coals are exclusively high-S coals

2 Se is considered as a high-coalphile element, though less coalphile than $\mathrm{S}$

3 the highest Se levels are related to the brackish environmental conditions

4 coal beds are sorption barriers for Se and associated $\mathrm{U}, \mathrm{Mo}, \mathrm{V}$ and $\mathrm{Pb}$ dissolved in oxic infiltration waters.

Kendall's tau correlation coefficients $(>0.99)$ calculated for the SHOS Raša samples were statistically significant $(\mathrm{p}<0.05)$ for all the pairs of elements $\mathrm{S}, \mathrm{Se}, \mathrm{V}$ and $\mathrm{U}$. This is in accordance with findings of Coleman et al. (1993) who pointed out that Se had positive correlations with S in US coal samples, and the authors also cited the highest known coal Se of $94,000 \mathrm{mg} / \mathrm{kg}$ found in a 'dirty' coal from China; according to them, selenium replaces S in organic complexes. The SHOS vanadium values (Figure 2) are also increased compared with coal Clarke values, especially when taking results published by Limić and Valković (1986). Similar V values (18.8-74.0 mg/kg) in high-S Indian coals were reported by Baruah and Khare (2010), while Liu et al. (2015) reported even higher $\mathrm{V}$ concentrations ranging from 573 to $1,180 \mathrm{mg} / \mathrm{kg}$. Zeng et al. (2005) reported ranges $(\mathrm{mg} / \mathrm{kg})$ of $\mathrm{U}(12.0-326)$ and V $(56.0-1,400)$ in Chinese sulphur-rich Heshan coal. Also, Dai et al. (2015) discussed enrichment of U, Se, Mo, Re and V in SHOS guiding coals (China) and reported $\mathrm{U}$, Se and V average values ( $\mathrm{mg} / \mathrm{kg}$ ) as follows: $211,35.3$ and 892 , respectively. Extremely high V level of $10,600 \mathrm{mg} / \mathrm{kg}$ in the Western Kentucky (USA) No. 9 coal rich in vanadium was discussed by Hower et al. (2000). From Figure 2, it can be seen that the low-S C samples have similar or even lower Se, V, U and $\mathrm{Hg}$ values compared to coal Clarke values, while their $\mathrm{Sr}$ values as well as $\mathrm{Sr}$ in A samples are increased compared to respective Clarke values. Figure 3 shows that the $\mathrm{C}$ as well as the SHOS samples are similar to coal Clarke values as regards the levels of $\mathrm{Cd}, \mathrm{Pb}, \mathrm{Cu}$ and $\mathrm{Zn}$. Only Cr is increased in the SHOS samples, particularly when the results of Limic and Valković (1986) are considered. Also, Cr was found to be positively correlated with S, $\mathrm{Se}, \mathrm{V}$ and $\mathrm{U}(0.66)$ in the SHOS samples, not significantly though $(\mathrm{p}>0.05)$. By 
comparison with the SHOS samples, Liu et al. (2015) found much higher $\mathrm{Cr}$ $(228-482 \mathrm{mg} / \mathrm{kg})$, and Cd $(2.39-6.32 \mathrm{mg} / \mathrm{kg})$ levels in Chinese SHOS coals. With respect to NE Indian (Baruah and Khare, 2010), and Indonesian (Singh et al., 2015) sulphur-rich coals, $\mathrm{Cr}$ and $\mathrm{Cd}$ levels $(\mathrm{mg} / \mathrm{kg})$ were as follows: up to 55.5 and 5.00 , and up to 58.7 and 2.90 , respectively.

It is noteworthy that the A (SHOS) median Se, V, U and Sr (Figure 2) as well as Cd and $\mathrm{Cr}$ (Figure 3 ) values are lower compared to the SHOS as well as the coal ash Clarke values. This is somewhat surprising as trace element concentrations are normally increased in ash by-products compared to parent coal (Natusch and Wallace, 1974; Clarke and Sloss, 1992), what is also evident for the C and A samples (Figures 2 and 3). It could be presumably ascribed to the oxidation and leaching processes in the environment. Namely, Lemly (1997), having reviewed environmental implications of selenium, pointed out that 'Rain can leach selenium from coal and oil-shale mining, preparation, and storage sites, where it may enter down-gradient streams and reservoirs through precipitation runoff'. Also, Dreher and Finkelman (1992) determined elevated concentrations $(0.60-0.90 \mathrm{mg} / \mathrm{L})$ of $\mathrm{Se}$ in the groundwater of a small backfill area at a surface mine; the authors interpreted it in the context of oxidation of selenium-bearing pyrite in the geological past, combined with mining operations which disturbed the overburden and altered its environment. Coleman et al. (1993) emphasised that modes of occurrence of Se must be examined so as to assess its environmental impact.

Table 1 Comparison of the A SHOS data with other relevant studies (a-e), all in $\mathrm{mg} / \mathrm{kg}$

\begin{tabular}{lcccccc}
\hline Element & $A($ SHOS $)$ & $a$ & $b$ & $c$ & $d$ & $e$ \\
\hline $\mathrm{Cd}$ & $0.14-0.88$ & $0.33-1.66$ & - & - & $<0.10$ & - \\
$\mathrm{Cr}$ & $14.5-38.2$ & $94.7-378$ & $69.6-250$ & $43.3-65.6$ & 128 & 208 \\
$\mathrm{Cu}$ & $28.4-120$ & $37.0-180$ & $19.0-64.0$ & $60.3-66.6$ & 89.8 & 359 \\
$\mathrm{Hg}$ & $0.02-0.79$ & $0.18-0.49$ & - & - & 0.01 & - \\
$\mathrm{Pb}$ & $1.50-144$ & $17.0-74.0$ & $24.6-74.0$ & $87.4-93.5$ & 25.7 & 145 \\
$\mathrm{Se}$ & $0.50-6.05$ & $2.70-21.0$ & - & - & 26.1 & - \\
$\mathrm{Sr}$ & $4.77-647$ & $176-542$ & $233-898$ & - & 798 & 286 \\
$\mathrm{U}$ & $0.50-25.2$ & $5.60-19.7$ & $34.0-277$ & $4.70-5.50$ & 22.9 & - \\
$\mathrm{V}$ & $11.2-624$ & $76.0-207$ & $146-630$ & $1,130-1,160$ & 179 & 356 \\
$\mathrm{Zn}$ & $5.73-229$ & $33.0-306$ & $56.0-307$ & $60.3-76.7$ & 38.1 & 152 \\
\hline
\end{tabular}

Notes: a - Oreščanin et al. (2012).

b - Oreščanin et al. (2005).

c - Marrero et al. (2007).

$\mathrm{d}$ - Mardon and Hower (2004).

e - Spears and Martinez-Tarrazona (2004).

Oreščanin et al. (2012) investigated an ash landfill (in central Croatia, some $100 \mathrm{~km} \mathrm{NE}$ from the Labin City), which is similar to the A (SHOS) site regarding its disposal and geochemistry, and found out increased levels of a number of trace elements in ash compared to control soil samples. Table 1 presents the comparison of element ranges in the A (SHOS) samples with other similar studies. It can be seen that minimum values of all A (SHOS) variables are much lower than respective values measured by Oreščanin et al. (2012), while the maximum variable values are either similar or higher than 
respective ones (Table 1, comparison with column 'a'). Also, regarding the A (SHOS) $\mathrm{Se}, \mathrm{U}$ and $\mathrm{V}$ values, it can be seen that much higher values were reported in other papers (Table 1, columns 'b', 'c' and 'd'). For instance, Mardon and Hower (2004) reported Se concentrations in fly ash and bottom ash [a medium sulphur, high volatile A bituminous Dean (Fire Clay) seam from Knox County, eastern Kentucky] as high as 239 and $26.1 \mathrm{mg} / \mathrm{kg}$, respectively. Kendall's tau correlations calculated for the A (SHOS) samples are presented in Table 2 . Based on positive $(>0.62)$ satistically significant $(\mathrm{p}<0.05)$ correlations, it is interesting to note that the so called SHOS coalphile U-V-Se association has been left preserved in the A (SHOS) landfill, while their relations towards S are negative $(<-0.33)$, and even statistically significant (against $\mathrm{Se}$ and $\mathrm{U})$. This, together with the abovementioned A (SHOS) decreasing trace element levels compared with Clarke values, could indicate on their possible environmentally hazardous leaching processes which should be explored by more detailed future studies. Namely, Miko et al. (2003) analysed soil samples collected from the immediate PPP's (Figure 1B) vicinity, and reported that their aqueous extracts had $0.1 \mathrm{mg} / \mathrm{L}$ of Se. They extracted up to $1.90 \mathrm{mg} / \mathrm{L}$ of Se from Raša coal ash by-products, thus exceeding the non-hazardous limit of $0.50 \mathrm{mg} / \mathrm{L}$. Compared with Se background groundwater values of $0.40 \mu \mathrm{g} / \mathrm{L}$; the authors measured $5.00 \mu \mathrm{g} / \mathrm{L}$ of Se in the water draining the abandoned mines and areas polluted with the SHOS Raša ash. They also found increased Mo, Mn, Ni, Cr, Sb, U, Br, $\mathrm{Fe}$ and I levels in that water.

Table 2 Kendall tau correlations of the A SHOS dana

\begin{tabular}{lccccccccccc}
\hline & $H g$ & $C d$ & $V$ & $S e$ & $P b$ & $S r$ & $C r$ & $Z n$ & $C u$ & $U$ & $S$ \\
\hline $\mathrm{Hg}$ & 1.00 & & & & & & & & & & \\
$\mathrm{Cd}$ & 0.05 & 1.00 & & & & & & & & & \\
$\mathrm{~V}$ & 0.14 & 0.14 & 1.00 & & & & & & & & \\
$\mathrm{Se}$ & 0.17 & 0.06 & $\mathbf{0 . 6 2}$ & 1.00 & & & & & & & \\
$\mathrm{~Pb}$ & 0.33 & -0.05 & -0.33 & 0.06 & 1.00 & & & & & & \\
$\mathrm{Sr}$ & -0.43 & 0.14 & -0.14 & $\mathbf{- 0 . 6 2}$ & -0.33 & 1.00 & & & & & \\
$\mathrm{Cr}$ & -0.24 & $\mathbf{- 0 . 6 2}$ & 0.24 & 0.17 & -0.33 & 0.05 & 1.00 & & & & \\
$\mathrm{Zn}$ & 0.43 & 0.24 & -0.05 & -0.06 & $\mathbf{0 . 7 1}$ & -0.24 & $-\mathbf{0 . 6 2}$ & 1.00 & & & \\
$\mathrm{Cu}$ & 0.05 & -0.14 & $\mathbf{0 . 7 1}$ & $\mathbf{0 . 7 3}$ & -0.05 & -0.24 & 0.52 & -0.33 & 1.00 & & \\
$\mathrm{U}$ & 0.39 & 0.06 & $\mathbf{0 . 6 2}$ & $\mathbf{0 . 7 3}$ & 0.06 & -0.39 & 0.17 & -0.06 & $\mathbf{0 . 7 3}$ & 1.00 & \\
$\mathrm{~S}$ & -0.24 & 0.14 & -0.33 & $\mathbf{- 0 . 6 2}$ & 0.05 & 0.43 & -0.33 & 0.33 & $\mathbf{- 0 . 6 2}$ & $\mathbf{- 0 . 6 2}$ & 1.00 \\
\hline
\end{tabular}

Note: Bold values significant at $\mathrm{p}<0.05$.

Finally, it is worth noting that the A sample of a dark/black colour (due to unburnt coal fraction) had trace element values 2-3 times those measured in the A sample of a grey colour. The latter had presumably underwent more efficient combustion and, hence, lost the trace element load which might have ended up in fly ash or in gaseous emissions (Clarke and Sloss, 1992; Xu et al., 2003; Saikia et al., 2015).

\subsection{Aquatic and herbal geochemistry}

Rybicka (1996) reviewed mining and metallurgical impact on the Polish environment, and proposed that "a combination of hydrological, chemical and/or geochemical investigations can provide much additional valuable information on concentrations of 
pollutants, e.g., trace metals, for the estimation of the environmental impact of mining and processing activities on rivers, groundwater and soils". Herewith, element measurements of biological, aquatic, airborne, and soil samples commonly give an insight into the effects of human activities such as fossil fuel combustion and mining on the environment (Adriano et al., 1980; Dreher and Finkelman, 1992; Kierczak et al., 2008; Dowarah et al., 2009; Csavina et al., 2012; Silva et al., 2012; Flues et al., 2013; Gomez-Gonzalez et al., 2014, 2015; Oliveira et al., 2014; Saikia et al., 2015). Since the Labin City area has represented the major Croatian coal mining, metal industry, and coal-fired electricity centre for more than two centuries (Medunić et al., 2016a), the local aquatic as well as terrestrial environments could have been presumably exposed to mine and/or ash wastes, and airborne particles from former as well as recent stacks' emissions by multiple pathways. Therefore, surface fresh and seawater samples together with three plant communities (clover, mushroom, and foliage) were analysed for their sulphate and elemental composition. A working hypothesis is that a possible seawater (SW, Figure 1B) contamination with trace elements could have been primarily derived from the PPP (low-S coal and ash airborne particles), while the herbal (F, M, C, Figure 1B) elemental composition could have been influenced by weathering/leaking processes of the $\breve{\text { S }}$ [A (SHOS)] site (Figure 1B). Namely, Harkness et al. (2016) identified the leaking of coal ash ponds to adjacent surface water and shallow groundwater in the Southeastern USA.

Sulphate levels measured in surface stream water samples (Figure 1E) ranged from $3.50 \mathrm{mg} / \mathrm{L}$ to $7.00 \mathrm{mg} / \mathrm{L}$. According to the Croatian regulation (OG, 2004) on the health safety of drinking water, the maximum value of sulphate in drinking water is set at $250 \mathrm{mg} / \mathrm{L}$. The obtained sulphate levels are very low, and they can be ascribed to the local alkaline carbonate environment which favours the precipitation of $\mathrm{CaSO}_{4}$. Although sulphur (sulphate form) is notorious for its role in acid/coalmine drainage problems (Burgos et al., 2012), the Raša coal is characterised by low pyritic and sulphate (below $0.50 \%$ ) sulphur levels (Chou, 1997). Hence, the sulphate levels dissolved in surface streams of the Labin City area are low and should not pose an environmental threat.

Table 3 Comparison of element values in plant (d.w.) and aquatic specimens with world ( $\mathrm{a}$ and $\mathrm{b}$ ) compiled values $(\mathrm{mg} / \mathrm{kg}$ and $\mu \mathrm{g} / \mathrm{L}$, respectively)

\begin{tabular}{lcccccccc}
\hline & $\begin{array}{c}\text { clover } \\
(\mathrm{mg} / \mathrm{kg})\end{array}$ & $\begin{array}{c}a \\
\text { (clover) }\end{array}$ & $\begin{array}{c}\text { foliage } \\
(\mathrm{mg} / \mathrm{kg})\end{array}$ & $\begin{array}{c}a \\
\text { (foliage) }\end{array}$ & $\begin{array}{c}\text { mushroom } \\
(\mathrm{mg} / \mathrm{kg})\end{array}$ & $\begin{array}{c}a \\
(\text { mushroom })\end{array}$ & $\begin{array}{c}\text { seawater } \\
(\mu \mathrm{L} / \mathrm{L})\end{array}$ & $\begin{array}{c}b \\
(\text { seawater })\end{array}$ \\
\hline $\mathrm{Hg}$ & 0.02 & $0.50-1.00$ & 0.04 & $0.50-1.00$ & 0.03 & 0.63 & & 0.03 \\
$\mathrm{Cd}$ & 0.04 & $0.46-0.80$ & 0.02 & $0.07-0.27$ & 0.23 & $12.0-24.0$ & 0.31 & 0.11 \\
$\mathrm{~V}$ & 2.84 & $8.00-13.0$ & 0.63 & $0.28-0.71$ & 0.62 & $0.05-2.00$ & 2.96 & 2.50 \\
$\mathrm{Se}$ & 2.31 & 0.09 & 1.90 & $0.09-0.19$ & 0.39 & $0.14-0.56$ & 1.07 & 0.20 \\
$\mathrm{~Pb}$ & 0.70 & 2.80 & 0.33 & $45.0-69.0$ & 0.37 & $0.50-300$ & 0.81 & 0.03 \\
$\mathrm{Sr}$ & 76.5 & $95.0-850$ & 132 & $45.0-70.0$ & 2.56 & & 10,300 & 7,900 \\
$\mathrm{Cr}$ & 2.99 & 1.00 & 0.86 & & 0.71 & $0.20-0.71$ & 1.37 & 0.30 \\
$\mathrm{Zn}$ & 23.7 & $24.0-45.0$ & 6.31 & $12.0-47.0$ & 10.4 & & 19.0 & 0.03 \\
$\mathrm{Cu}$ & 11.0 & 6.00 & 6.95 & & 6.31 & & 18.8 & 0.25 \\
$\mathrm{U}$ & 0.02 & $0.001-0.06$ & 0.02 & $0.001-0.06$ & 0.02 & $0.001-0.01$ & & 3.20 \\
\hline
\end{tabular}

Notes: a - Kabata-Pendias (2010).

b - Reimann and de Caritat (1998). 
As regards the trace element levels in the SW sample (Table 3): it is evident that $\mathrm{Cd}$, Se, $\mathrm{Pb}, \mathrm{Cr}, \mathrm{Zn}$ and $\mathrm{Cu}$ exceeded compiled environmental data (Reimann and de Caritat, 1998). This could be attributed to the elevated levels of $\mathrm{Cd}, \mathrm{Pb}, \mathrm{Cu}, \mathrm{Zn}$ and $\mathrm{Cr}$ in the A samples (Figure 3) derived from recent low-S (C) coal combustion activities in the PPP (Figure 1B). Their Se and $\mathrm{V}$ values are only slightly increased compared to Clarke values (Figure 2) and, therefore, the SW Se and V levels could have derived either from the wind-driven dispersion processes of the A particles, or due to the legacy of the former SHOS combustion processes (Medunić et al., 2016b), or the both. Elevated selenium levels measured in aquatic specimens from the Labin City area (Miko et al., 2003), together with the results in Table 3, provide an evidence for the potential leaking of coal ash deposits around the PPP, what should be investigated by future more detailed studies. Such studies are necessary as Fulekar and Dave (1986) reported that Se was found among the elements extracted either by water or acid, and particularly in effluent waters related to disposed coal ash by-products. Furthermore, the authors point out that $\mathrm{Cd}$ and $\mathrm{Pb}$ were found by previous studies to be correlated with human health problems due to coal combustion. Also, by referring to previously published papers, Dreher and Finkelman (1992) emphasise that excessive selenium has been identified as a cause of peridontal disease and dental caries in humans and as a possible carcinogen.

Table 3 shows that slightly increased levels in herbal species were found for the following trace elements: $\mathrm{Se}$ in all three species, $\mathrm{Sr}$ in foliage, $\mathrm{Cr}$ in clover and mushroom, $\mathrm{Cu}$ in clover, and $\mathrm{U}$ in mushroom. This was somewhat expected, particularly regarding Se, as soil from the Labin City area was found to be either contaminated or polluted with a range of contaminants due to the past SHOS combustion activities (Miko et al., 2003; Medunić et al., 2016b, 2016c). Also, Figures 2 and 3 show that these elements exhibited increased levels either in coal or ash material. Similarly, Paikaray (2016) reported that many areas in India show Se toxicity having resulted from coal mining and coal-fired power plants. The author emphasised that the problem can be regarded as being even more serious when taking into account that India is the third largest global coal producer. Considering $\mathrm{Se}$, due to its strong tendency for bioaccumulation, its concentration is commonly increased in the plant tissue and, therefore, poses toxic hazards by entering the food chain (Lemly, 1997). Terry et al. (2000) summarised findings about Se physiology and biochemistry in plants, and reported that tissue Se levels in 17 different crops, growing on soils containing moderate Se concentrations, rarely exceeded $1.00 \mathrm{mg} / \mathrm{kg} \mathrm{Se}$ (dry weight). Yoshida and Muramatsu (1997) determined in Japanese forests' mushroom specimens U ranges 0.004-0.012 $\mathrm{mg} / \mathrm{kg}$ (dry weight), what is slightly lower than the results from this study (Table 3). Gadd and Fomina (2011) highlighted fungal interactions and transformations of $U$ species, and proposed that 'The dependence of almost all land plants on symbiotic mycorrhizal fungi, and the fact that mycorrhizal fungi are capable of uranium transformations may make fungal biogeochemical activity of importance in phyto- or other bioremediation strategies for soils polluted with various forms of uranium'. This could be potentially applicable in case of the Labin City soil polluted with U (Medunić et al., 2016c). 


\section{Conclusions}

The main outcome of this research is the fact that selenium was found to be slightly increased in aquatic (seawater) and herbal (clover and foliage) specimens; they were collected from the Labin City localities either close to coal ash by-products disposed into the unlined surface site Šrmac (related to the SHOS Raša coal combustion), or the vicinity of the PPP powered by low-S coal. Since the Strmac site Se values were found to be decreased compared to relevant previous studies on SHOS Raša coal ash by-products, they could indicate a possible leaking problem in the study area. The values of potentially toxic trace metals $(\mathrm{Cd}, \mathrm{Pb}, \mathrm{Cr}, \mathrm{Zn}$ and $\mathrm{Cu})$ were slightly increased in seawater compared to world values, what was attributed to the respective elevated levels in today's ash derived from the low-S coal combustion. Our ongoing studies are focused on the local hydrogeochemistry, edible vegetable element composition, and human health risk assessment related to soil geochemistry. Furthermore, future research will involve better understanding of phase composition and element speciation in environmental (soil) samples compared with coal and ash samples.

\section{Acknowledgements}

Financial support from the Croatian Science Foundation through the project 7555 TRACESS is acknowledged. The first author (G.M.) is grateful to Mr. Mladen Bajramović (Istrian coal mines Raša) who helped with sampling, advices, and old documents. Gratitude also goes to Dr. Milko Jakšić for providing us with Raša coal and ash samples. We thank Dr. James C. Hower (UKY), and an anonymous reviewer for helpful comments which substantially improved the paper.

\section{References}

Adriano, D.C., Page, A.L., Elseewi, A.A., Chang, A.C. and Straughan, I. (1980) 'Utilization and disposal of fly ash and other coal residues in terrestrial ecosystems: a review', Journal of Environmental Quality, Vol. 9, No. 3, pp.333-344.

ASTM E775-87 (1996) Standard Test Methods for Total Sulfur in the Analysis Sample of Refuse-Derived Fuel, ASTM International, West Conshohocken, PA [online] http://www.astm.org (accessed 5th March 2016).

Badr, O. and Probert, S.D. (1994) 'Atmospheric sulphur: trends, sources, sinks and environmental impacts', Applied Energy, Vol. 47, No. 1, pp.1-67.

Baruah, B.P. and Khare, P. (2010) 'Mobility of trace and potentially harmful elements in the environment from high sulfur Indian coal mines', Applied Geochemistry, Vol. 25, No. 11, pp.1621-1631.

Bauman, A. and Horvat, Đ. (1981) 'The impact of natural radioactivity from a coal-fired power plant', Science of the Total Environment, Vol. 17, No. 1, pp.75-81.

Bläsing, M., Hasir, N.B.A. and Müller, M. (2015) 'Release of inorganic elements from gasification and co-gasification of coal with miscanthus, straw, and wood at high temperature', Energy \& Fuels, Vol. 29, No. 11, pp.7386-7394. 
Burgos, W.D., Borch, T., Troyer, L.D., Luan, F., Larson, L.N., Brown, J.F., Lambson, J. and Shimizu, M. (2012) 'Schwertmannite and Fe oxides formed by biological low-pH Fe(II) oxidation versus abiotic neutralization: impact on trace metal sequestration', Geochimica et Cosmochimica Acta, Vol. 76, pp.29-44.

Chou, C-L. (1990) Geochemistry of Sulfur in Fossil Fuels, Chapter 2, ACS Symposium Series, Vol. 429, pp.30-52.

Chou, C-L. (1997) 'Geologic factors affecting the abundance, distribution, and speciation of sulfur in coals', in Qi, Y. (Ed.): Proc. 30th Int'l Geol. Congr., Vol. 18, Part B, pp.47-57.

Chou, C-L. (2012) 'Sulfur in coals: a review of geochemistry and origins', International Journal of Coal Geology, Vol. 100, pp.1-13.

Clarke, L.B. and Sloss, L.L. (1992) Trace Elements - Emissions from Coal Combustion and Gasification, IEACR/49, IEA Coal Research, London, 111pp.

Coleman, L., Bragg, L.J. and Finkelman, R.B. (1993) 'Distribution and mode of occurrence of selenium in US coals', Environmental Geochemistry and Health, Vol. 15, No. 4, pp.215-227.

Csavina, J., Field, J., Taylor, M.P., Gao, S., Landázuri, A., Betterton, E.A. and Sáez, A.E. (2012) 'A review on the importance of metals and metalloids in atmospheric dust and aerosol from mining operations', Science of the Total Environment, Vol. 433, pp.58-73.

Dai, S., Ren, D., Zhou, Y., Chou, C-L., Wang, X., Zhao, L. and Zhu, X. (2008) 'Mineralogy and geochemistry of a superhigh-organic-sulfur coal, Yanshan Coalfield, Yunnan, China: evidence for a volcanic ash component and influence by submarine exhalation', Chemical Geology, Vol. 255, pp.182-194.

Dai, S., Seredin, V.V., Ward, C.R., Hower, J.C., Xing, Y., Zhang, W., Song, W. and Wang, P. (2015) 'Enrichment of U-Se-Mo-Re-V in coals preserved within marine carbonate successions: geochemical and mineralogical data from the Late Permian Guiding Coalfield, Guizhou, China', Mineralium Deposita, Vol. 50, No. 2, pp.159-186.

Dai, S., Zhang, W., Seredin, V.V., Ward, C.R., Hower, J.C., Wang, X., Li, X., Song, W., Zhao, L., Kang, H., Zheng, L. and Zhou, D. (2013a) 'Factors controlling geochemical and mineralogical compositions of coals preserved within marine carbonate successions: a case study from the Heshan Coalfield, southern China', International Journal of Coal Geology, Vols. 109-110, pp.77-100.

Dai, S., Zhang, W., Ward, C.R., Seredin, V.V., Hower, J.C., Li, X., Song, W., Wang, X., Kang, H., Zheng, L., Wang, P. and Zhou, D. (2013b) 'Mineralogical and geochemical anomalies of late Permian coals from the Fusui Coalfield, Guangxi Province, southern China: influences of terrigenous materials and hydrothermal fluids', International Journal of Coal Geology, Vol. 105, pp.60-84.

Dowarah, J., Deka Boruah, H.P., Gogoi, J., Pathak, N., Saikia, N. and Handique, A.K. (2009) 'Eco-restoration of a high-sulphur coal mine overburden dumping site in northeast India: a case study', Journal of Earth System Science, Vol. 118, No. 5, pp.597-608.

Dreher, G.B. and Finkelman, R.B. (1992) 'Selenium mobilization in a surface coal mine, Powder River Basin, Wyoming, U.S.A.', Environmental Geology and Water Sciences, Vol. 19, No. 3, pp.155-167.

Durn, G., Ottner, F. and Slovenec, D. (1999) 'Mineralogical and geochemical indicators of the polygenetic nature of terra rossa in Istria, Croatia', Geoderma, Vol. 91, Nos. 1-2, pp.125-150.

Dutta, M., Saikia, J., Taffarel, S.R., Waanders, F.B., de Medeiros, D.,Cutruneo, C.M.N.L., Silva, L.F.O. and Saikia, B.K. (2017) 'Environmental assessment and nano-mineralogical characterization of coal, overburden and sediment from Indian coal mining acid drainage', Geoscience Frontiers, January [online] http://dx.doi.org/10.1016/j.gsf.2016.11.014.

Ernečić, G., Lovrenčić Mikelić, I. and Medunić, G. (2014) 'Distribution of 226Ra in the surface soil in the vicinity of the thermal power plant Plomin (Croatia)', in Pál-Molnár, E. (Ed.): Acta Mineralogica-Petrographica, Abstract Series, p.28, Szeged, Hungary. 
Fiket, Ž., Medunić, G. and Kniewald, G. (2016) 'Rare earth elements distribution in soil nearby thermal power plant', Environmental Earth Sciences, Vol. 75, pp.598 [online] http://dx.doi.org/10.1007/s12665-016-5410-2.

Fiket, Ž., Roje, V., Mikac, N. and Kniewald, G. (2007) 'Determination of arsenic and other trace elements in bottled waters by high resolution inductively coupled plasmamass spectrometry', Croatica Chemica Acta, Vol. 80, No. 1, pp.91-100.

Finkelman, R.B. (1994) 'Modes of occurrence of potentially hazardous elements in coal: levels of confidence', Fuel Processing Technology, Vol. 39, Nos. 1-3, pp.21-34.

Flues, M., Sato, I.M., Scapin, M.A., Cotrim, M.E.B. and Camargo, I.M.C. (2013) 'Toxic elements mobility in coal and ashes of Figueira coal power plant, Brazil', Fuel, Vol. 103, pp.430-436.

Frančišković-Bilinski, S., Scholger, R., Bilinski, H. and Tibljaš, D. (2014) 'Magnetic, geochemical and mineralogical properties of sediments from karstic and flysch rivers of Croatia and Slovenia', Environmental Earth Sciences, Vol. 72, No. 10, pp.3939-3953.

Fulekar, M.H. and Dave, J.M. (1986) 'Disposal of fly ash - an environmental problem', International Journal of Environmental Studies, Vol. 26, No. 3, pp.191-215.

Gadd, G.M. and Fomina, M. (2011) 'Uranium and fungi', Geomicrobiology Journal, Vol. 28, Nos. 5-6, pp.471-482.

Gomez-Gonzalez, M.A., Garcia-Guinea, J., Laborda, F. and Garrido, F. (2015) 'Thallium occurrence and partitioning in soils and sediments affected by mining activities in Madrid province (Spain)', Science of The Total Environment, Vol. 536, pp.268-278.

Gomez-Gonzalez, M.A., Serrano, S., Laborda, F. and Garrido, F. (2014) 'Spread and partitioning of arsenic in soils from a mine waste site in Madrid province (Spain)', Science of The Total Environment, Vols. 500-501, pp.23-33.

Halamić, J., Peh, Z., Miko, S., Galović, L. and Šorša, A. (2012) 'Geochemical atlas of Croatia: environmental implications and geodynamical thread', Journal of Geochemical Exploration, Vol. 115, pp.36-46.

Hamrla, M. (1960) 'K razvoju in stratigrafiji produktivnih liburnijskih plasti Primorskega krasa', Rudarsko-Metalurški Zbornik, Vol. 3, pp.203-216.

Harkness, J.S., Sulkin, B. and Vengosh, A. (2016) 'Evidence for coal ash ponds leaking in the Southeastern United States', Environmental Science and Technology, Vol. 50, No. 12, pp.6583-6592.

Hower, J.C., Greb, S.F., Cobb, J.C. and Williams, D.A. (2000) 'Discussion on origin of vanadium in coals: parts of the Western Kentucky (USA) No. 9 coal rich in vanadium', Journal of the Geological Society, Vol. 157, No. 125, pp.1257-1259, London.

Kabata-Pendias, A. (2010) Trace Elements in Soils and Plants, 4th ed., CRC Press/Taylor \& Francis Group, Boca Raton, FL, USA, ISBN: 978-1-4200-9368-1, 548pp.

Kasrai, M., Brown, J.R., Bancroft, G.M., Yin, Z. and Tan, K.H. (1996) 'Sulphur characterization in coal from X-ray absorption near edge spectroscopy', International Journal of Coal Geology, Vol. 32, Nos. 1-4, pp.107-135.

Ketris, M.P. and Yudovich, Y.E. (2009) 'Estimations of Clarkes for carbonaceous biolithes: world averages for trace element contents in black shales and coals', International Journal of Coal Geology, Vol. 78, No. 2, pp.135-148.

Kierczak, J., Neel, C., Aleksander-Kwaterczak, U., Helios-Rybicka, E., Bril, H. and Puziewicz, J. (2008) 'Solid speciation and mobility of potentially toxic elements from natural and contaminated soils: a combined approach', Chemosphere, Vol. 73, No. 5, pp.776-784.

Kuklińska, K., Cieszynska, M., Wolska, L. and Namiesnik, J. (2013) 'Analytical and bioanalytical problems associated with the toxicity of elemental sulfur in the environment', Trends in Analytical Chemistry, Vol. 48, pp.14-21.

Lemly, A.D. (1997) 'Environmental implications of excessive selenium: a review', Biomedical and Environmental Sciences, Vol. 10, pp.415-435. 
Limić, N. and Valković, V. (1986) 'The occurrence of trace elements in coal', Fuel, Vol. 65, No. 8, pp.1099-1102.

Liu, J., Yang, Z., Yan, X., Ji, D., Yang, Y. and Hu, L. (2015) 'Modes of occurrence of highly-elevated trace elements in superhigh-organic-sulfur coals', Fuel, Vol. 156, pp.190-197.

Mardon, S.M. and Hower, J.C. (2004) 'Impact of coal properties on coal combustion by-product quality: examples from a Kentucky power plant', International Journal of Coal Geology, Vol. 59, Nos. 3-4, pp.153-169.

Marović, G., Senčar, J., Kovač, J. and Prlić, I. (2004) 'Improvement of the radiological environmental situation due to remedial actions at a coal-fired power plant', Journal of Radioanalytical and Nuclear Chemistry, Vol. 261, No. 2, pp.451-455.

Marrero, J., Polla, G, Jimenez, R., Pla, R., Gomez, D. and Smichowski, P. (2007) 'Characterization and determination of 28 elements in fly ashes collected in a thermal power plant in Argentina using different instrumental techniques', Spectrochimica Acta B, Vol. 62, No. 2, pp.101-108.

Marshall, C.E. and Draycott, A. (1954) Petrographic, Chemical and Utilization Studies of the Tangorin High Sulphur Seam, Greta Coal Measures, New South Wales, 1954/1, Department of Geology and Geophysics Memoir, University of Sydney, 66pp.

Medunić, G., Ahel, M., Božičević Mihalić, I., Gaurina Srček, V., Kopjar, N., Fiket, Ž., Bituh, T. and Mikac, I. (2016b) 'Toxic airborne S, PAH, and trace element legacy of the superhigh-organic-sulphur Raša coal combustion: cytotoxicity and genotoxicity assessment of soil and ash', Science of the Total Environment, Vol. 566, pp.306-319.

Medunić, G., Rađenović, A., Bajramović, M., Švec, M. and Tomac, M. (2016a) 'Once grand, now forgotten: what do we know about the superhigh-organic-sulphur Raša coal?', Rudarskogeološko-naftni zbornik, Vol. 34, pp.27-45.

Medunić, G., Šabarić, J., Krivohlavek, A., Divjak, D., Rađenović, A., Kampić, Š. and Šeparović, A. (2016c) 'Sulphur and heavy metal pollution of the coal-based city soil (Labin, Croatia)', Goldschmidt Abstracts, p.2041.

Miko, S., Prohić, E., Durn, G. and Šparica, M. (2003) 'Selenium distribution and mobility in Mediterranean karst soils from a coal mining region in Istria, Croatia', in Farmer, J. (Ed.): 6th International Symposium on Environmental Geochemistry, pp.214-214, ISEG, Edinburgh.

Mohorović, L. (2003) 'The level of maternal methemoglobin during pregnancy in an air-polluted environment', Environmental Health Perspectives, Vol. 111, No. 16, pp.1902-1905.

Natusch, D.F.S. and Wallace, J.R. (1974) 'Urban aerosol toxicity: the influence of particle size', Science, Vol. 186, No. 4165, pp.695-699.

Oden, S. (1976) 'The acidity problem - an outline of concepts', Water, Air and Soil Pollution, Vol. 6, pp.137-166.

OG (2004) Regulations on Health Quality of Drinking Water, 48/04, in Croatian.

Oliveira, M.L.S., Marostega, F., Taffarel, S.R., Saikia, B.K.,Waanders, F.B., DaBoit, K., Baruah, B.P. and Silva, L.F.O. (2014) 'Nano-mineralogical investigation of coal and fly ashes from coal-based captive power plant (India): an introduction of occupational health hazards', Science of the Total Environment, Vols. 468-469, pp.1128-1137.

Oreščanin, V., Barišić, D., Mikelić, L., Lovrenčić, I., Mačefat, M.R., Pavlović, G. and Lulić, S. (2005) 'The influence of fly and bottom ash deposition on the quality of Kaštela Bay sediments', Environmental Geology, Vol. 49, No. 1, pp.53-64.

Oreščanin, V., Kollar, R., Buben, K., Mikelić, I.L., Kollar, K., Kollar, M. and Medunić, G. (2012) 'Chemical and radiological characterization of fly and bottom ash landfill of the former sulfate pulp factory Plaški and its surroundings', Journal of Environmental Science and Health. Part A, Toxic/Hazardous Substances \& Environmental Engineering, Vol. 47, No. 11, pp.1592-1606.

Paikaray, S. (2016) 'Origin, mobilization and distribution of selenium in a soil/water/air system: a global perspective with special reference to the Indian scenario', CLEAN - Soil, Air, Water, Vol. 44, No. 5, pp.474-487. 
Peh, Z., Miko, S. and Hasan, O. (2010) 'Geochemical background in soils: a linear process domain? An example from Istria (Croatia)', Environmental Earth Sciences, Vol. 59, pp.1367-1383.

Rađenović, A. (2004) 'Sumpor u ugljenu (Sulphur in coal, in Croatian)', Kemija u Industriji, Vol. 53, No. 12, pp.557-565.

Rađenović, A. (2006) 'Inorganic constituents in coal', Kemija u Industriji, Vol. 55, No. 2, pp.65-71.

Reimann, C. and de Caritat, P. (1998) Chemical Elements in the Environment. Factsheets for the Geochemist and Environmental Scientist, Springer-Verlag, Berlin Heidelberg, 398pp.

Rybicka, E.H. (1996) 'Impact of mining and metallurgical industries on the environment in Poland', Applied Geochemistry, Vol. 11, Nos. 1-2, pp.3-9.

Saikia, B.K. and Ninomiya, Y. (2011) 'An investigation on the heterogeneous nature of mineral matters in Assam (India) coal by CCSEM technique', Fuel Processing Technology, Vol. 92, No. 5, pp.1068-1077.

Saikia, B.K., Hower, J.C., Hood, M.M., Baruah, R., Dekaboruah, H.P., Boruah, R., Sharma, A. and Baruah, B.P. (2015) 'Petrological and biological studies on some fly and bottom ashes collected at different times from an Indian coal-based captive power plant', Fuel, Vol. 158, pp.572-581.

Senko, J.M., Bertel, D., Quick, T.J. and Burgos, W.D. (2011) 'The influence of phototrophic biomass on Fe and $\mathrm{S}$ redox cycling in an acid mine drainage-impacted system', Mine Water and the Environment, Vol. 30, No. 1, pp.38-46.

Silva, L.F.O., DaBoit, K., Sampaio, C.H., Jasper, A., Andrade, M.L., Kostova, I.J., Waanders, F.B., Henke, K.R. and Hower, J.C. (2012) 'The occurrence of hazardous volatile elements and nanoparticles in Bulgarian coal fly ashes and the effect on human health exposure', Science of the Total Environment, Vol. 416, pp.513-526.

Singh, A.L., Singh, P.K., Singh, M.P. and Kumar, A. (2015) 'Environmentally sensitive major and trace elements in Indonesian coal and their geochemical significance', Energy Sources, Part A: Recovery, Utilization, and Environmental Effects, Vol. 37, No. 17, pp.1836-1845.

Sinninghe Damsté, J.S., White, C.M., Green, J.B. and de Leeuw, J.W. (1999) 'Organosulfur compounds in sulfur-rich Raša coal', Energy \& Fuels, Vol. 13, No. 3, pp.728-738.

Smith, J.W. and Batts, B.D. (1974) 'The distribution and isotopic composition of sulfur in coal', Geochimica et Cosmochimica Acta, Vol. 38, No. 1, pp.121-133.

Sołek-Podwika, K., Ciarkowska, K. and Kaleta, D. (2016) 'Assessment of the risk of pollution by sulfur compounds and heavy metals in soils located in the proximity of a disused for 20 years sulfur mine (SE Poland)', Journal of Environmental Management, Vol. 180, pp.450-458.

Spears, D.A. and Martinez-Tarrazona, M.R. (2004) 'Trace elements in combustion residues from a UK power station', Fuel, Vol. 83, Nos. 17-18, pp.2265-2270.

Speight, J.G. (2005) Handbook of Coal Analysis, John Wiley \& Sons, Inc., Hoboken, New Jersey, 222pp.

Speight, J.G. (2013) Coal-Fired Power Generation Handbook, Scrivener Publishing LLC, Salem, 760pp.

Stergaršek, A., Valković, V. and Injuk, J. (1988) 'Sposobnost pepela Raškog ugljena za vezivanje sumpor-dioksida iz dimnog plina termoelektrane', Zaštita atmosfere, Vol. 16, pp.6-8.

Terry, N., Zayed, A.M., de Souza, M.P. and Tarun, A.S. (2000) 'Selenium in higher plants', Annual Review of Plant Physiology and Plant Molecular Biology, Vol. 51, pp.401-432.

Valković, V., Makjanić, J., Jakšić, M., Popović, S., Bos, A.J.J., Vis, R.D., Wiederspahn, K. and Verheul, H. (1984) 'Analysis of fly ash by X-ray emission spectroscopy and proton microbeam analysis', Fuel, Vol. 63, No. 10, pp.1357-1362.

Vejahati, F., Xu, Z. and Gupta, R. (2010) 'Trace elements in coal: Associations with coal and minerals and their behavior during coal utilization - a review', Fuel, Vol. 89, No. 4, pp.904-911. 
Ward, C.R., Li, Z. and Gurba, L.W. (2007) 'Variations in elemental composition of macerals with vitrinite reflectance and organic sulphur in the Greta Coal Measures, New South Wales, Australia', International Journal of Coal Geology, Vol. 69, No. 3, pp.205-219.

White, C.M., Douglas, L.J., Anderson, R.R., Schmidt, C.E. and Gray, R.J. (1990) 'Organosulfur constituents in Raša coal', in Orr, W. et al. (Eds.): Geochemistry of Sulfur in Fossil Fuels, ACS Symposium Series, Vol. 429, pp.261-286, American Chemical Society, Washington, DC.

Xu, M., Yan, R., Zheng, C., Qiao, Y., Han, J. and Sheng, C. (2003) 'Status of trace element emission in a coal combustion process: a review', Fuel Processing Technology, Vol. 85, Nos. 2-3, pp.215-237.

Yoshida, S. and Muramatsu, Y. (1997) 'Determination of major and trace elements in mushroom, plant and soil samples collected from Japanese forests', International Journal of Environmental Analytical Chemistry, Vol. 67, Nos. 1-4, pp.49-58.

Yudovich, Y.E. and Ketris, M.P. (2006) 'Selenium in coal: a review', International Journal of Coal Geology, Vol. 67, Nos. 1-2, pp.112-126.

Zeng, R., Zhuang, X., Koukouzas, N. and Xu, W. (2005) 'Characterization of trace elements in sulphur-rich Late Permian coals in the Heshan coal field, Guangxi, South China', International Journal of Coal Geology, Vol. 61, Nos. 1-2, pp.87-95.

Zerklea, A.L., Kamyshny, A.Jr., Kump, L.R., Farquhar, J., Oduro, H. and Arthur, M.A. (2010) 'Sulfur cycling in a stratified euxinic lake with moderately high sulfate: constraints from quadruple S isotopes', Geochimica et Cosmochimica Acta, Vol. 74, No. 17, pp.4953-4970. 